\title{
Biosorption Characteristics of Mn (II) by Bacillus cereus Strain HM-5 Isolated from Soil Contaminated by Manganese Ore
}

\author{
Xu Zhenggang,, ${ }^{1,}$ Ding Yi ${ }^{1}$, Huang Huimin', Wu Liang1, Zhao Yunlin ${ }^{1 *}$, Yang Guiyan ${ }^{1 *}$ \\ ${ }^{1}$ Hunan Research Center of Engineering Technology for Utilization of Environmental and Resources Plant, \\ Central South University of Forestry and Technology, Changsha, Hunan, China \\ ${ }^{2}$ School of Material and Chemical Engineering, Hunan City University, Yiyang, Hunan, China
}

Received: 12 December 2017

Accepted: 27 January 2018

\begin{abstract}
Our study navigated investigated the metal adsorption ability of bacterial Bacillus cereus strain HM-5 isolated from manganese ore. The effects of $\mathrm{pH}$, initial metal ions concentration, biomass dose, contact time, and temperature on biosorption were studied. The results showed that the biosorption capacity of the B. cereus strain HM-5 for the metallic ions reached up to $98.9 \%$ for Mn at $600 \mathrm{mg} / \mathrm{L}$ initial metal ion concentration. The biosorptoin was most affected by $\mathrm{pH}$ and incubation temperature. Optimal $\mathrm{pH}$ and temperature were 6 and $35^{\circ} \mathrm{C}$, respectively. Optimal contact time was $5 \mathrm{~d}$ for biosorption by $B$. cereus strain HM-5. The surface chemical functional groups of $B$. cereus biomass identified by Fourier transform infrared (FTIR) were hydroxyl, alkyl, amide, phosphoryl, and phosphoric acid groups, which may be involved in the biosorption of heavy metals. SEM micrographs indicated that B. cereus HM-5 cells were irregular and cracked with the appearance of wrinkles and many flocs on the surface after Mn stress. The results showed that the selected bacteria had good application prospect in manganese-contaminated soil remediation.
\end{abstract}

Keywords: Bacillus cereus, Heavy metal, Biosorption, Manganese

\section{Introduction}

In recent years, industrial production activities such as quarry opening, metal plating, steel production, dyestuff, and chemical industries release alarmingly higher amounts of heavy metals into the natural environment [1-5]. The accumulation of these heavy metals in soils may lead to a decline in soil fertility through their negative effects on heterogeneous microbial

*e-mail: zy18291290@163.com, yangguiyan@yahoo.com communities living in the soil. Also, through the food chain, heavy metals are known to cause toxic effects on both plant and human health [6-7]. Heavy metal pollution has become one of the most serious environmental problems in recent years, so it has become important to find an eco-friendly and efficient way to repair metalcontaminated environments and protect the health of the deteriorating environment [8]. Conventional methods for removing metals include chemical precipitation, ion exchange, activated charcoal, solvent extraction, electrochemical treatment, membrane technologies, and chemical oxidation-reduction [9-11]. But these conventional methods are generally expensive and have 
many limitations. In contrast, biosorption as a relatively young, inexpensive, and socially acceptable technology has caught great attention due to its potential to provide an effective, green, and economic means for heavy-metal repair [12-13].

In the early 1980s some scholars put forward the method of using microbial function to control heavy metals-contaminated soil, the basic principle being the use of microbial metabolism to fix heavy metal ions or convert the toxic heavy metal ions into non-toxic or low toxicity valence state [14]. Biosorption of heavy metals usually is divided into three categories: cell-surface binding, intracellular accumulation, and extracellular accumulation [15]. The mechanism of cell surface adsorption is mainly that the functional groups of the cell wall - $\mathrm{COOH},-\mathrm{NH}_{2},-\mathrm{PO}_{3}{ }^{4}-$, - $\mathrm{OH}$, etc., are combined with metal ions or coordinate with each other in other ways [16]. Xiong Fen et al. have found that the $-\mathrm{OH}$, $-\mathrm{COOH}$, and C-O-C groups in the EPS of Aspergillus fumigatus are the main groups associated with $\mathrm{Pb}^{2+}[17]$. Research shows that the cell-surface binding can occur in either living or non-living microorganisms, but the intracellular and extracellular accumulation of metals are usually energy-driven processes, thus taking place only in live cells [18]. Because the bioaccumulation process is directly related to cell metabolism, many factors that affect the biological activity of cells (such as $\mathrm{pH}$, temperature, ion initial concentration, contact time, and biomass dose, etc.) will have a significant impact on the detoxification function of microorganisms [15].

Manganese (Mn) is a widely distributed metal, but also an essential trace nutrient in all known forms of life [19]. So the problem of $\mathrm{Mn}$ contamination is not taken seriously like other heavy metals such as cadmium, lead, mercury, and copper. However, excessive intake of manganese is harmful to the human body, leading to neuropathic poisoning and a reduction in intelligence quotients in school-age children [20-22]. Mn in the environment is different and difficult to degrade. Normally $\mathrm{Mn}$ is removed by adding some basic chemical to the drainage prior to returning them to the environment. Chemical oxidation could be performed to Mn removal by adding strong oxidizing agents or by aeration, although they are often expensive and inefficient and produce secondary pollutants such as toxic byproducts. How to rationally and effectively control this pollution has become a hot research topic in China and internationally.

Research shows that we can screen out a large number of corresponding anti-resistant microorganisms from the heavy metal-contaminated soil and these can be used for heavy metal-contaminated soil bioremediation [23-24]. In recent years, many researchers have carried out the work of anti-manganese microbial screening and utilization: Han et al. separated three strains with strong ability to remove $\mathrm{Mn}$ and excellent resistance to $\mathrm{Mn}$ from manganese-contaminated soil and water, and they were identified as Xylose colorless, Oxidizing bacilli, and
Serratia marcescens [25]. Studies involving the use of Bacillus, Saccharomyces cerevisiae, and Pseudomonas $s p$. 4-05 have reported the high efficiency of $\mathrm{Mn}$, and even the removal rate was up to $95.82 \%[8,26-$ 27]. Xue et al. reported that Serratia $s p$ isolated from the Xiangtan Mn mine possesses strong Mn removal capability [28].

There is a valuable microbe bank in the mining area and the microbe resources can supply not only microbial repair tools but also ecological safety. In order to know more details about Bacillus cereus strain HM-5, which was isolated from soils of Xiangtan Mn ore wasteland. The molecular characterization, ability of the bacteria to reduce $\mathrm{Mn}$, and the effects of the process parameters such as initial $\mathrm{Mn}$ concentration, $\mathrm{pH}$, temperature, contact time, and inoculation dose of B. cereus strain HM-5 on biosorption were investigated in the present study. At the same time, SEM analysis was carried out to reveal the cell surface changes in cell-surface after biosorption. In addition, fourier transform infrared (FTIR) analytical technique was also made to determine the functional groups of bacterial surface.

\section{Materials and Methods}

\section{Collection of Samples}

The slag soil samples were collected from Xiangtan Mn mine, Hunan, China $\left(112^{\circ} 45^{\prime} \mathrm{E} \sim 122^{\circ} 55^{\prime} \mathrm{E}, 27^{\circ} 53^{\prime} \mathrm{N} \sim\right.$ $28^{\circ} 03^{\prime} \mathrm{N}$ ), where mining activity has a long history and has played an important role in both economic development and environmental pollution. There has been serious heavy metal pollution and the survey reports showed that $\mathrm{Mn}$ concentration in soil was up to $20,041 \mathrm{mg} / \mathrm{Kg}$ [29]. All tools have been sterilized and slag samples were shaken through a 100-mesh sieve. Then the small slag soil was mixed evenly and placed in a sterile EP tube. The samples were quickly stored in a refrigerator at $-4^{\circ} \mathrm{C}$ after backing into the laboratory, as a screening substrate for resistant strains.

\section{Selecting High Mn-Tolerant Bacterial Strains}

$10 \mathrm{~g}$ of dry soil sample was dissolved in $90 \mathrm{ml}$ distilled water and diluted in sterilized distilled water to get a concentration range of 10-2 to 10-4 dilution and coated on nutrient agar solid plates (peptone $10 \mathrm{~g}$, beef jelly powder $3 \mathrm{~g}, \mathrm{NaCl} 5 \mathrm{~g}$, agar $20 \mathrm{~g}$, deionized water $1 \mathrm{~L}, \mathrm{pH}$ 5.5-6.0) supplemented with different $\mathrm{Mn}^{2+}$ concentrations at $30^{\circ} \mathrm{C}$ for $3 \mathrm{~d}$ in the biochemical incubator (SPX-250B, China), observing the growth of the strains and increased $\mathrm{Mn}^{2+}$ concentration in the solid medium. Finally, we selected the resistant to the highest concentration of the strain as the target strain. The gradually increased concentration of $\mathrm{Mn}^{2+}$ was $500 \mathrm{mg} / \mathrm{L}, 1,000 \mathrm{mg} / \mathrm{L}, 1,500 \mathrm{mg} / \mathrm{L}, 2,000 \mathrm{mg} / \mathrm{L}$, $3,000 \mathrm{mg} / \mathrm{L}$, and $4,000 \mathrm{mg} / \mathrm{L}$. The target strain was stored at $-4^{\circ} \mathrm{C}$ in the beef-protein slant medium. 


\section{Identifying Mn-Tolerant Bacterial Strains}

\section{Bacterial Characterization}

By screening, strain HM-5 showing the highest adsorption, and was selected and characterised morphologically and biochemically. The properties of the strain HM-5 that included Gram reaction, methyl red test, indole production test, Voges Proskauer, hydrogen sulfide test, gelatine liquefaction test, citrate utilisation test, and starch hydrolysis were determined by the standard methods given in Bergey's Manual of Determinative Bacteriology [30].

\section{Identification Based on $16 S \mathrm{rDNA}$}

The partial sequencing of $16 \mathrm{~S}$ rDNA gene sequence of the strain HM-5 was carried out commercially by DNA sequencing service, Jimei biotechnology company, Shanghai China (www.majorbio.com) using universal primers, 518F (5'-CCAGCAGCCGCGGTAATACG-3') and 800R (5'-TACCAGGGTATCTAATCC-3'). Later, nucleotide sequence data were deposited in the Gen-Bank sequence database. The online program BLAST was used to find out the related sequences with known taxonomic information in the databank at the NCBI (ncbi.nlm.nih.gov/BLAST) to accurately identify the strain HM-5. The nucleotide sequences of 16S rDNA were aligned, and a phylogenetic tree was constructed using Mega 7.0 software based on the neighbour-joining method [30-31].

\section{Batch Adsorption Experiments}

The factors that affect the biosorption capacity and growth of the HM-5 strain were examined in a batch system. All batch experiments were carried out in 250 $\mathrm{ml}$ conical Erlenmeyer flasks with $100 \mathrm{ml}$ metal solution on a rotary shaker at $120 \mathrm{r} / \mathrm{min}$. The effect of initial metal concentration on biosorpition was evaluated in the concentration range of $(0-2000 \mathrm{mg} / \mathrm{L})$. Then $1 \mathrm{ml}$ of bacterial suspension was added to the metal solution and the reaction mixture was shaken on a constant temperature shaker at $120 \mathrm{rpm}$ and $30^{\circ} \mathrm{C}$ for $5 \mathrm{~d}$, which was enough for adsorption equilibrium. Similarly, inoculation dose of the strain $(0.1-3 \mathrm{ml})$, contact time $(0-5 \mathrm{~d})$, temperature $\left(10-40^{\circ} \mathrm{C}\right)$, and $\mathrm{pH}(3-9)$ were performed on the metals species sorption. In the biosorption experiments, unless otherwise stated, the initial metal concentration, temperature, and strain dose were $600 \mathrm{mg} / \mathrm{L}, 30^{\circ} \mathrm{C}$ and $1 \mathrm{ml}$, respectively. The growth values of the strains were determined by ultraviolet spectrophotometer (UV-2450, China) at $600 \mathrm{~nm}$ (OD600). The bacteria suspension was separated by centrifugation (TD5A, China) at 5,000 rpm for $10 \mathrm{~min}$, and the supernatant was analyzed for residual metal concentration by flame atomic absorption spectrophotometry (AA7000, Japan). All tests were done in triplicate. The manganese removal rate was calculated using the following equation:

$$
P=\frac{C_{0}-C}{C_{0}} \times 100 \%
$$

...where $P$ is the removal rate of manganese, $C_{0}$ is the initial concentration of metal ion $(\mathrm{mg} / \mathrm{L})$, and $C e$ is the final concentration of metal ion $(\mathrm{mg} / \mathrm{L})$.

\section{FTIR Analysis}

Fourier transform infrared spectroscopy (FTIR) was used to identify the main chemical functional groups of the strain HM-5. Bacterial cell samples before and after biosorption were obtained by centrifugation at $8,000 \mathrm{rpm}$ for $10 \mathrm{~min}$ and mixed with $2 \% \mathrm{KBr}$. The mixtures were compressed into translucent sample disks and fixed in the FTIR spectrometer for analysis (Wave number range of $400 \mathrm{~cm}^{-1}-4000 \mathrm{~cm}^{-1}$ ).

\section{SEM Analysis}

In order to observe how the sorption of metal ions on the cell surface would alter the cell-surface morphology, SEM was adopted in this study. Metalloaded and metal-free strain samples were fixed with glutaraldehyde for $2 \mathrm{~h}$, followed by dehydrating with a graded series of ethanol $(30-100 \%, 15-20$ min each). The pretreated samples were coated with $\mathrm{Au}$ via vapor deposition prior to being introduced to SEM for analysis.

\section{Results and Discussion}

\section{Characterization and Molecular Identification of the Strain HM-5}

In this study, a highly effective Mn-resistant strain HM-5 was screened from the soil of Mn mining area by gradient acclimation culture. The selected bacterial strain was characterized and identified using standard morphological, physiological, and biochemical tests. Gram reaction, indole, hydrogen sulfide test were negative, while citrate utilization, methyl red, Voges Proskauer, starch hydrolysis, and gelatin liquefaction were positive (Table 1). On the basis of the characteristics observed for strain HM-5 and compared with those listed in Bergey's Manual of Determinative Bacteriology, strain HM-5 was presumptively identified as Bacillus sp. In order to structure the phylogenetic tree and identify the position of the above strain HM-5, it was subjected to 16S rDNA gene sequence analysis. The sequence of 16S rDNA of strain HM-5 was submitted to Gen-Bank (Gen-Bank accession number: MF926244). A similar search was performed by using the BLAST program that indicated a genetic similarity of strain HM-5 with the 16S rDNA sequence of Bacillus cereus NR 114422.1 (16S rDNA: 99\% similarity with the reference strain FM926244) in the NCBI database. A phylogenetic tree was constructed by MEGA 7 software based on 
Table 1. Physiological and biochemical characteristics of the strain HM-5.

\begin{tabular}{|c|c|}
\hline Tests employed & Characteristics observed \\
\hline $\begin{array}{c}\text { Accession number } \\
\text { Morphology }\end{array}$ & MF926244 \\
\hline Gram reaction & - \\
\hline Shape & Rod \\
\hline Pigments & - \\
\hline Biochemical reactions & \\
\hline Citrate utilisation & + \\
\hline Indole & - \\
\hline Methyl red & + \\
\hline Voges Proskauer & + \\
\hline $\begin{array}{c}\text { Hydrogen sulfide test } \\
\text { Hydrolysis }\end{array}$ & - \\
\hline Starch hydrolysis & + \\
\hline Gelatin liquefaction & + \\
\hline
\end{tabular}

"+" and "-"” indicate positive and negative reactions, respectively
16S rDNA partial sequence and presented in Fig. 1. Such a higher identical value confirmed the strain HM-5 to be $B$. cereus and was named B. cereus strain HM-5 in the study.

\section{Survival and Biosorption Characteristics on Different Initial Metal Concentrations}

Survival characteristics and the effect of initial metal concentration on metal biosorption by bacteria suspension of B. cereus strain HM-5 is shown in Fig. 2. Culture process of $B$. cereus strain HM-5 showed that Mn could promote the growth of strains at a low initial metal ion concentration. The biomass of $B$. cereus strain $\mathrm{HM}-5$, indicated by $\mathrm{OD}_{600}$ on $200 \mathrm{mg} / 1,400 \mathrm{mg} / 1,600$ $\mathrm{mg} / \mathrm{l}$, and $800 \mathrm{mg} / \mathrm{l}$ were larger than without $\mathrm{Mn}(0$ $\mathrm{mg} / \mathrm{l}, \mathrm{P}<0.05)$. The analysis of $\mathrm{OD}_{600}$ differences under the initial ion concentration shown that the growth of the strain reached equilibrium at $600 \mathrm{mg} / \mathrm{L}$. Mn was inhibited at $1,000 \mathrm{mg} / \mathrm{l}$. The maximum strain biomass reached a maximum $\mathrm{OD}_{600}$ of 2.21 for $\mathrm{Mn}$ at $800 \mathrm{mg} / \mathrm{l}$.

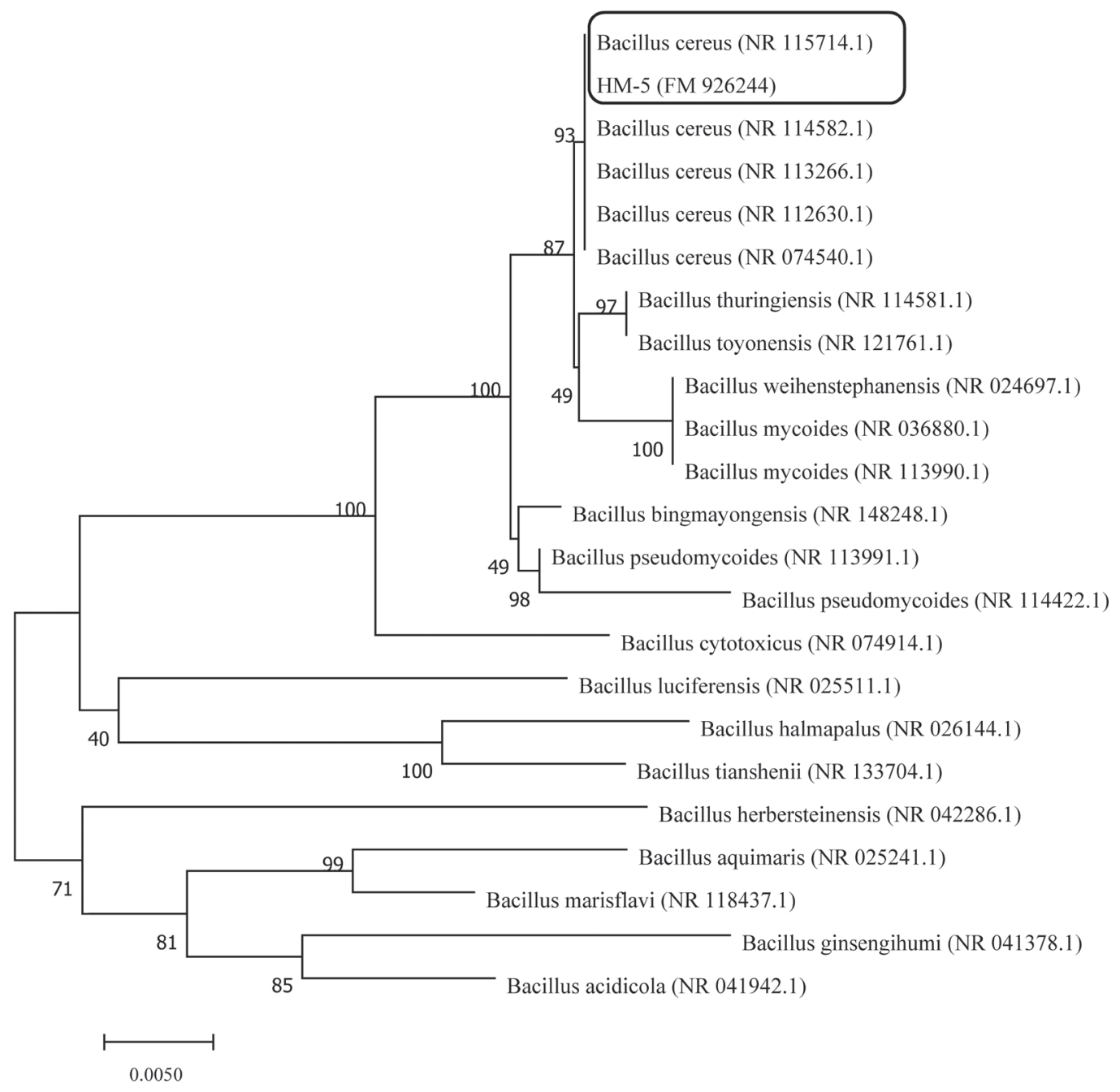

Fig. 1. The phylogenetic tree based on 16S rDNA sequence of strain HM-5. Phylogenetic position of strain HM-5 inferred by neighbourjoining method (NJ) of $16 \mathrm{~S}$ rDNA sequence; the bootstrap values were based on 1,000 replicates, showing next to the nodes and cutoff value is $75 \%$; the position of strain HM-5 is shown in the box. 


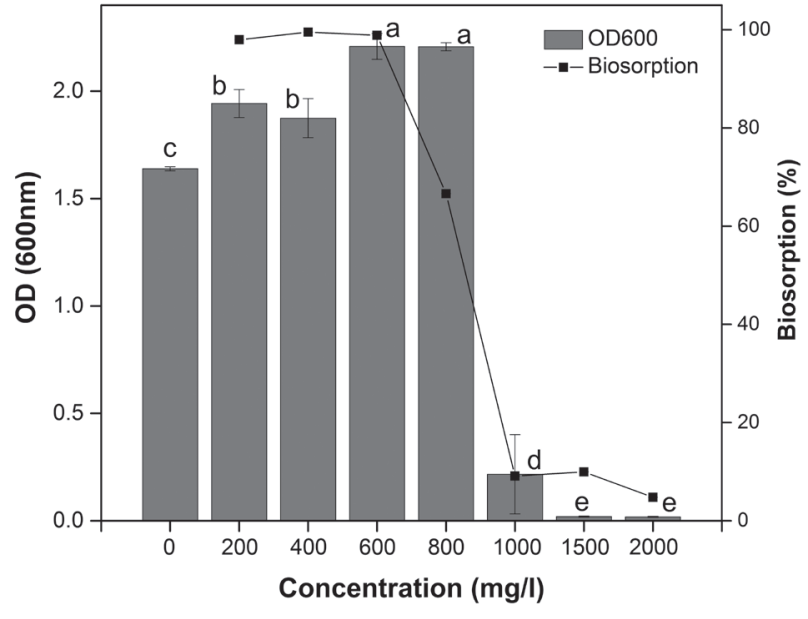

Fig. 2. Survival and biosorption characteristics of Bacillus cereus strain HM-5 on different initial metal concentrations.

However, the strain biomass decreased with an increase in metal ion concentration as the initial ion concentration more than $800 \mathrm{mg} / \mathrm{l}$ and the strains hardly grow of $\mathrm{OD}_{600}$ 0.02 at $2,000 \mathrm{mg} / \mathrm{l}$ for $\mathrm{Mn}$. This may be due to heavy metal toxicity inhibiting the growth of the bacteria at a high initial metal ion concentration (Fig. 2).

Meanwhile, it was observed that absorption rate is higher at low concentrations, but abruptly decreased with increasing manganese ion concentration. The maximum biosorption of metal was recovered at a low initial metal ion concentration, for example it was $99 \%$ for $\mathrm{Mn}$ at $600 \mathrm{mg} / \mathrm{l}$ while it was $67 \%$ at $800 \mathrm{mg} / 1 \mathrm{Mn}$, although the biomass was high at $800 \mathrm{mg} / \mathrm{l}$ (Fig. 2). The decrease in the percentage of biosorption may be attributed to the lack of sufficient free sites for metal biosorption. At lower concentrations all metal ions present in the solution could interact with the binding sites and thus the biosorption percentage was likely to become higher than at higher ion concentrations, as found in this study. Similar results have been reported by others [32-34].

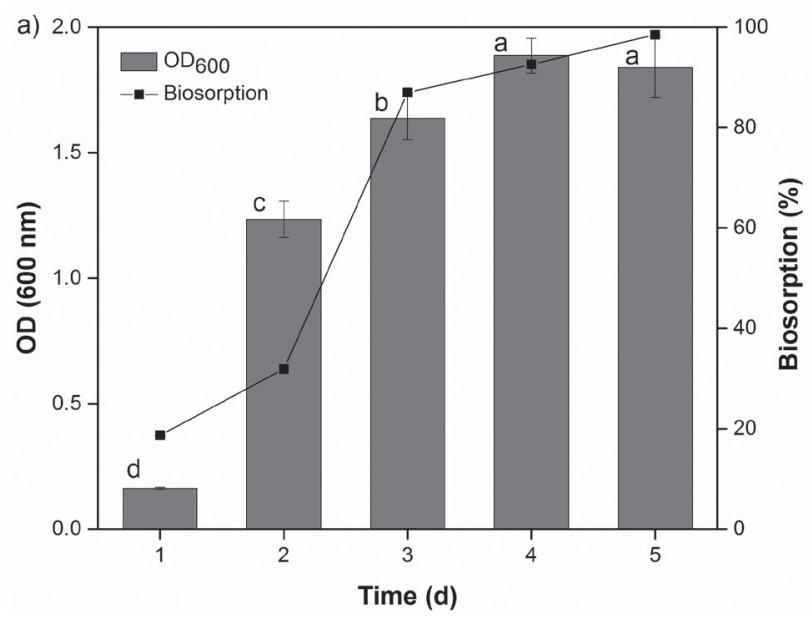

\section{Effect of Contact Time on Biosorption}

Contact time is one of the important factors of biosorption process. The biosorption of Mn by B. cereus strain HM-5 is shown in Fig. 3. It can be seen from Fig. 3a) that the biomass of the strain and the removal rate of heavy metal increased rapidly in the beginning, but after 3 days the rate of biosorption and the biomass of the strain slowed and reached an equilibrium. In this context, some reports here also observed that the previous period of sorption process is important for a high rate of metal sorption [35-36].

We can see from Fig. 3b) that with the increase of the reaction time, the biomass of the strain increased continuously, and the $\mathrm{pH}$ of the corresponding solution also increased. On the third day, the $\mathrm{pH}$ of the solution increased from 6.5 at the beginning to about 7.9, and the solution became alkaline.

\section{Effect of $\mathrm{pH}$ on Biosorption}

Solution initial $\mathrm{pH}$ is a critical parameter for adsorption experiments [37]. The $\mathrm{pH}$ strongly influences the solution chemistry of the metals, the activity of functional groups (carboxylate, phosphate, and amino groups) on the cell wall, and the competition of metallic ions for the binding site [38]. In order to see whether $\mathrm{pH}$ plays any role in the biosorption process or not, we set an experiment with varying $\mathrm{pH}$ to evaluate their effect on biosorption capacity of microbial biomass (Fig. 4). The optimum biosorption occurred at 6 for $\mathrm{Mn}$ and the best growth point of the strain occurred at 5. From 3 to 6 , with the $\mathrm{pH}$ increase, the removal rate of heavy metals increased the same as the biomass of the strain from 3 to 5 . However, when the $\mathrm{pH}$ exceeds the appropriate point, as it increased, biomass and removal rate will soon decrease. The variation in biosorption of heavy metals by microbial biomass at different $\mathrm{pH}$ could be due to the differences in the sensitivity of cell wall molecules of the bacterial cells to $\mathrm{pH}$ [33]. For instance, at low $\mathrm{pH}$,

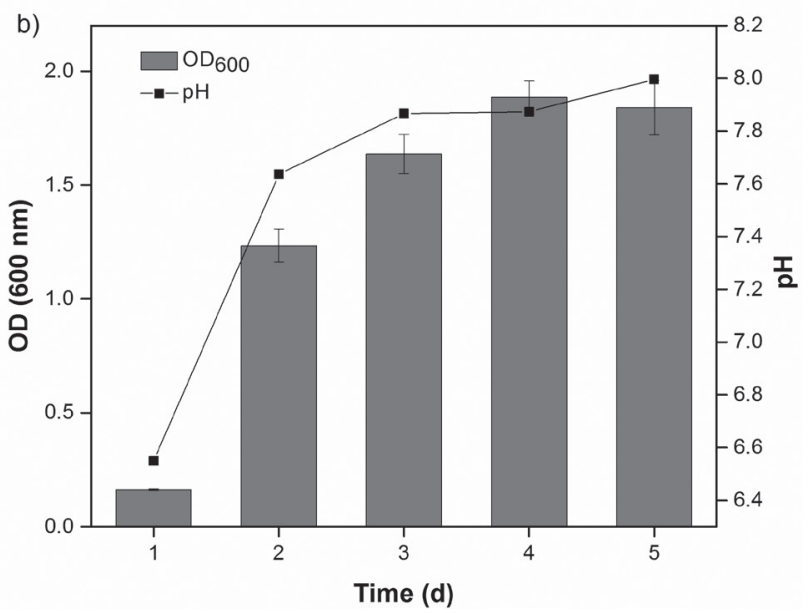

Fig. 3. Biosorption of heavy metals by Bacillus cereus strain HM-5 over the reaction time. 


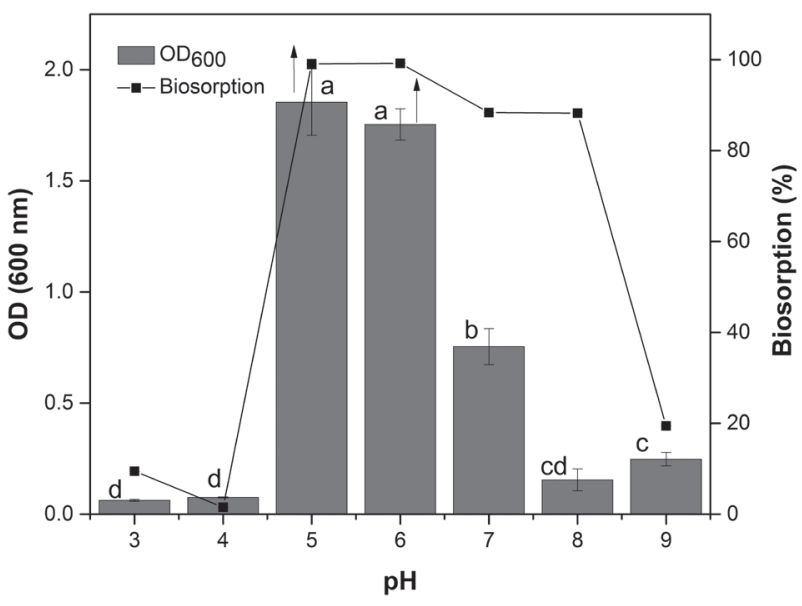

Fig. 4. Effect of $\mathrm{pH}$ on biosorption by Bacillus cereus strain HM-5.

cell wall ligands tightly bind with the hydronium ions $\mathrm{H}_{3} \mathrm{O}^{-}$and hence restrict the approach of metal cations due to repulsive force. On the contrary, at higher $\mathrm{pH}$ values, the metal ions on the cell surface may form hydrogen and oxygen chemical precipitation, which can affect the cell enzyme and other carriers to help transport, thus affecting the adsorption of bacteria and causing bacteria for a metal ions adsorption rate decrease $[34,39-40]$. Similar results have been reported by others $[16,41]$.

It can be seen from Fig. 4 that $\mathrm{pH}$ has a significant effect on the growth of the strain, which grew well in the weak acid environment. At 5 and 6, the biomass and adsorption rates of the strains were relatively high, and the $\mathrm{pH}$ of the solution after the reaction rose to 8.75 and 8.78 from the initial state, and the solution became alkaline. This may be due to the chemical reaction of bacteria in the adsorption of heavy metals, which changed the $\mathrm{pH}$ of the solution. Compared to other conditions, the strain did not grow well and the solution $\mathrm{pH}$ did not change significantly before and after reaction.

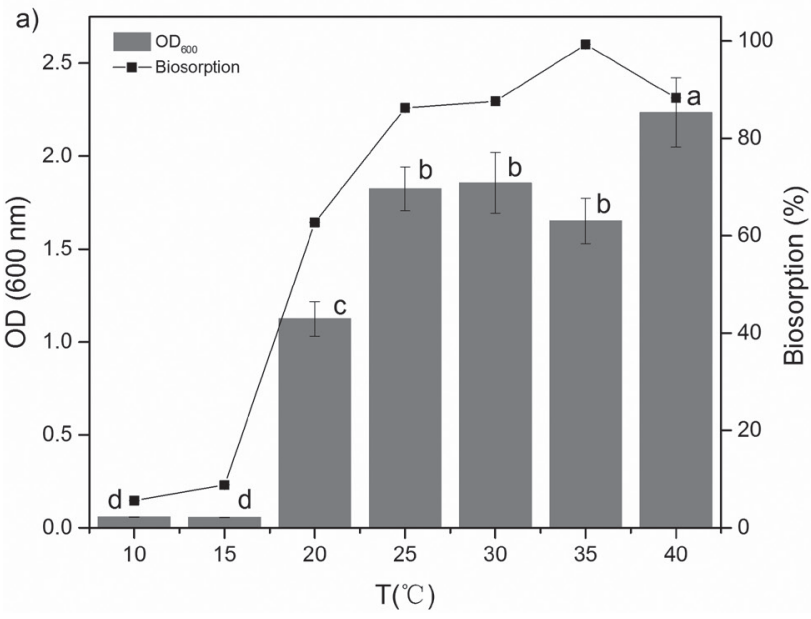

\section{Effect of Temperature on Biosorption}

Temperature is one of the most important factors for microbial growth. It can directly affect a variety of microbial biochemical reactions, affecting enzyme activity [42]. Excessive temperature can lead to protein denaturation, RNA pyrolysis, and cause microbes to stop growing and dying. Low temperature will reduce the level of microbial metabolism; when the body of water forms ice crystals, the cell wall will cause mechanical damage. So the appropriate temperature is essential for the growth of microorganisms [43]. The effect of different temperatures on the growth of the strain and metal removal rate is shown in Fig. 5a). In the range of $10-40^{\circ} \mathrm{C}$, the biomass of the strain increased with the rise of temperature. At $40^{\circ} \mathrm{C}$, the strain reached the maximum biomass. Meanwhile, in the range of $10-35^{\circ} \mathrm{C}$, the biosorption of metal increased with an increase in temperature. The maximum metal removal rate reached $99.3 \%$ at $35^{\circ} \mathrm{C}$. When the temperature was higher than $35^{\circ} \mathrm{C}$, the adsorption capacity decreased slightly. This may be due to the fact that the temperature is too high to affect the activity of the extracellular polymer, thereby reducing the biosorption of metal [44]. The effect of temperature on the efficiency of microbial adsorption of heavy metals in the suitable temperature range for cell growth is not big. It can be seen from Fig. 5b) that with the increase of temperature, the biomass of the strain increased continuously and the $\mathrm{pH}$ of the corresponding solution also increased continuously. When the temperature reaches $20^{\circ} \mathrm{C}$, the $\mathrm{pH}$ of the solution increases sharply from 6.59 at $10^{\circ} \mathrm{C}$ to 8.24 , and the solution becomes alkaline. This may be related to microbial adsorption of heavy metals.

\section{Effect of Inoculation Dose of the Strain on Biosorption}

Studies have shown that biofilm has a significant effect on the behavior of heavy metals in the water

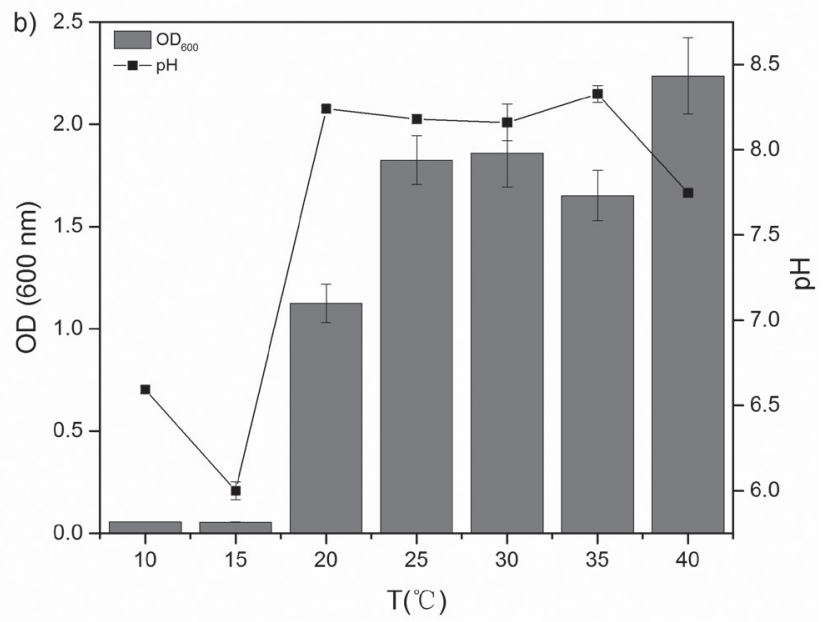

Fig. 5. Effect of temperature on biosorption by Bacillus cereus strain HM-5. 

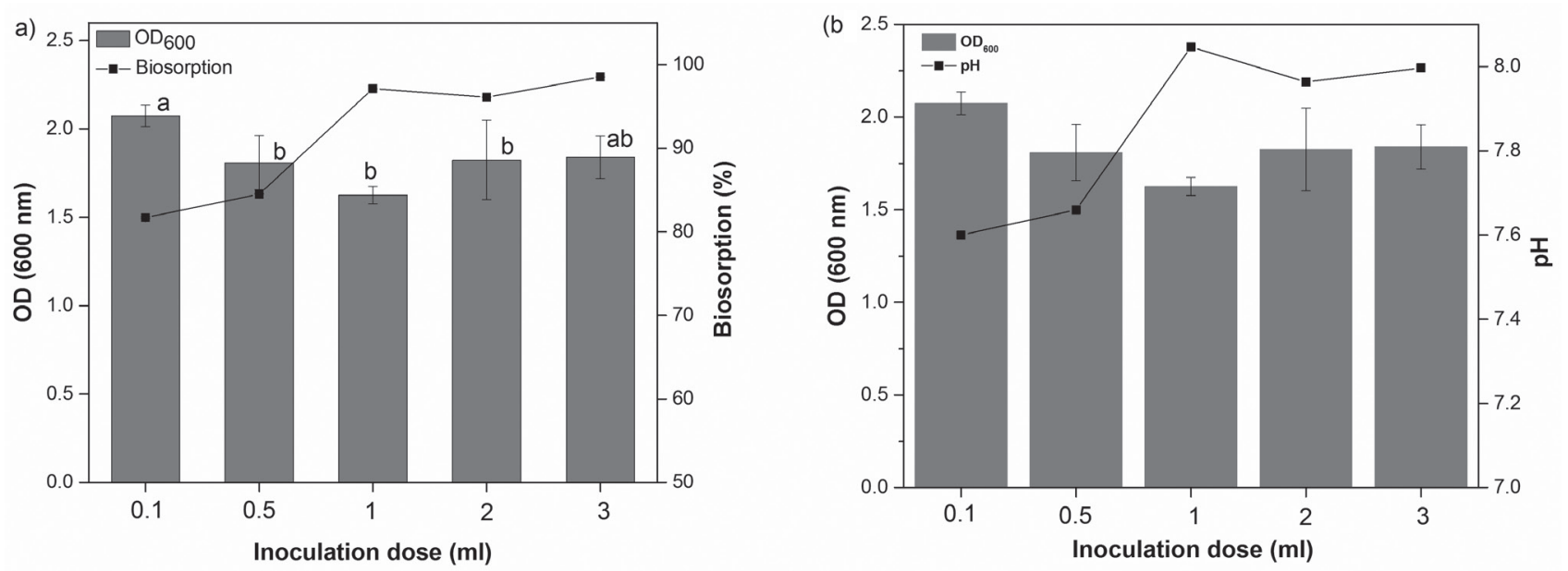

Fig. 6. Effect of inoculation dose of Bacillus cereus strain HM-5 on biosorption.

environment, especially metal oxide on the membrane, which plays a dominant role in biofilm adsorption of heavy metals [41]. Inoculation amount is directly related to the size of the membrane area, which has great influence on adsorption efficiency. It can be seen from Fig. 6a) that when the inoculation amount is less than $1 \mathrm{ml}$, the adsorption efficiency increases with the increase of inoculation quantity, and after more than $1 \mathrm{ml}$ it tends to be stable. This indicates that in the adsorption system determined by the metal concentration, the removal rate of heavy metals is increased as long as the adsorption sites on the surface of the cells do not reach saturation [45-47]. But when the amount of cells increases after a certain amount of dosage, and then continues to increase, the effect on the removal rate is not obvious. The effect of inoculation amount on strain growth was not significant. At the inoculation amount of 0.1 , the strain had the largest biomass. The strains will soon run out the nutrients of the medium due to the too large inoculation amount, and growth cycle of the strain could be shortened [48]. For comprehensive consideration the choice of inoculation amount was $1 \mathrm{ml}$.

As can be seen from Fig. 6b), the $\mathrm{pH}$ of the solution after the reaction at different inoculation amounts did not differ significantly.

\section{Cell Surface Change by FTIR Analysis}

Biosorption of metal ions by the microbial biomass depends largely on the functional groups present on the active sites of bacterial cells and physiochemical conditions of the solution. And hence, in order to better understand the kinds of functional groups involved in the biosorption process, FT-IR analysis of the biomass HM-5 was carried out. By comparing the infrared spectra of HM-5 before and after absorbing Mn, it can be seen that the maximum absorption peak of the hydroxyl group is broadened, and the location moved from $3,420 \mathrm{~cm}^{-1}$ to $3,415 \mathrm{~cm}^{-1}$; the absorption peak of the $2,960 \mathrm{~cm}^{-1}$ and $2,930 \mathrm{~cm}^{-1}$ was mainly caused by stretching vibration of the alkyl in the protein, carbohydrates, and other substances, and its strength weakened; the absorption peak of the amide $\mathrm{I}$ zone $(\mathrm{C}=\mathrm{O}$ stretching vibration $)$ at $1,650 \mathrm{~cm}^{-1}$ was weaker than before adsorption, and its location moved from $1,650 \mathrm{~cm}^{-1}$ to $1,655 \mathrm{~cm}^{-1}$; the absorption peak of the amide II zone (N-H bending vibration and $\mathrm{C}-\mathrm{N}$ stretching vibration superposition) at $1,540 \mathrm{~cm}^{-1}$ disappeared after adsorption; the absorption peak of the phosphoryl $(\mathrm{P}=\mathrm{O}$ stretching vibration) at $1,400 \mathrm{~cm}^{-1}$ was weaker than before adsorption and its peak type was widening; the absorption peak at $1,230 \mathrm{~cm}^{-1}$ is caused by the asymmetric stretching vibration of $\mathrm{P}=\mathrm{O}$ of the phosphate group, and the peak disappears after adsorption; the absorption peak at $1,080 \mathrm{~cm}^{-1}$ is caused by $\mathrm{P}=\mathrm{O}$ symmetric stretching vibration, and the intensity of adsorption is stronger and the position migrates to $1,070 \mathrm{~cm}^{-1}$ after adsorption (Fig. 7).

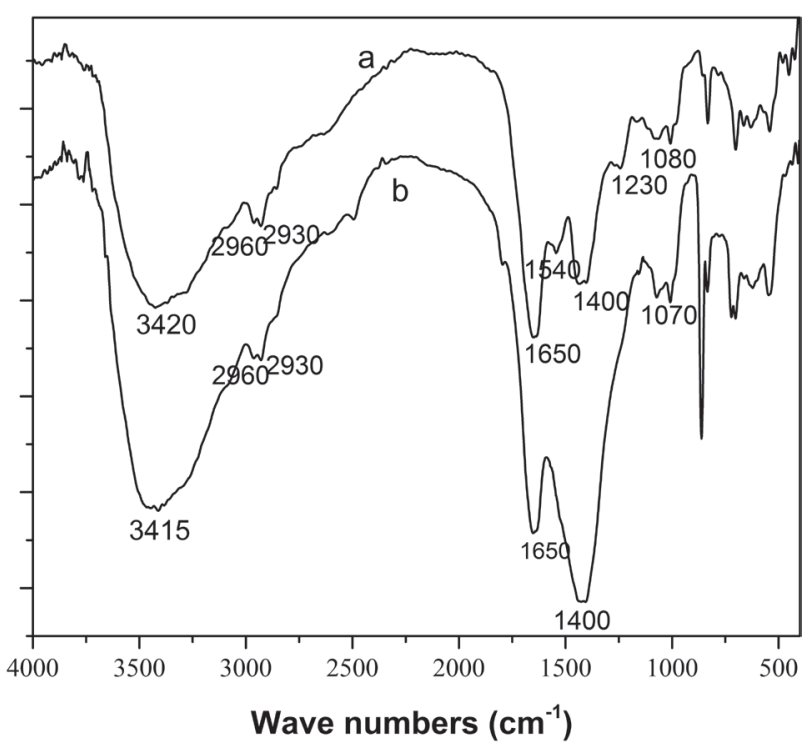

Fig. 7. IR spectrogram of Bacillus cereus HM-5 before a) and after b) absorbing Mn. 
a)

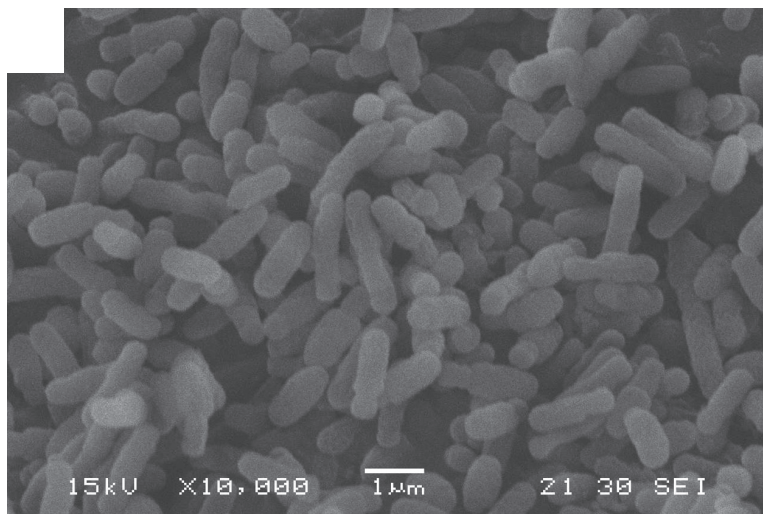

b)

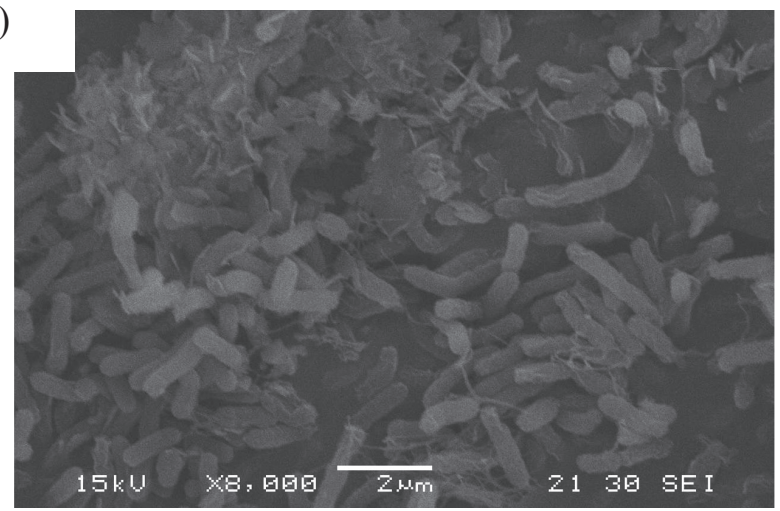

Fig. 8. Scanning electron micrograph of Bacillus cereus HM-5 before a) and after b) absorbing Mn.

Therefore, FTIR analysis shows that the functional groups involved in the adsorption process may have hydroxyl, alkyl, amide, phosphoryl, and phosphoric acid groups.

\section{Surface Morphology by Scanning Electron Microscopy}

Electron microscopic examination of HM-5 before and after metal removal was undertaken to locate the active sites of the cell wall. The SEM micrographs showed that HM-5 grown without $\mathrm{Mn}$ was morphologically rod-shaped with a smooth and complete surface as demonstrated in Fig. 8a). The average diameter of the cells was approximately $0.8 \mu \mathrm{m}$. After equilibration with a metal solution, the cell wall, shape and size of the bacteria changed (Fig. 8b). The length and size of the cell decreased, and the cells were irregular and cracked with the appearance of wrinkles on the surface. After adsorption of heavy metals, there are many flocs on the surface of the strain, and this may produce alkaline substances through the redox reaction. These changes suggest that the metal ions were entrapped in the extracellular polymeric substances of HM-5, thus causing deformation and damage to the cell surface during $\mathrm{Mn}$ absorption [49].

\section{Conclusion}

As an alternative to the basic chemical method, bioremediation has been shown to be a viable strategy for Mn (II) removal. Many microorganism species, including bacterial and fungi strains, that are capable of bioremediation of $\mathrm{Mn}$ (II) have been identified. Bacillus sp. SG-1, Pseudomonas putida strains MnB1 and GB-1, and Leptothrix discophora strains SS-1 and SP-6 are examples of bacteria that have been extensively studied [50]. Bacillus sp. has been identified as one of the best bacteria based on former research [51]. B. cereus, as an Mn-oxidizing and -reducing microorganism, was isolated from biofilms in chlorinated drinking water systems [52]. In this study, the B. cereus strain-HM5, an Mn-resistant strain isolated from manganese ore soil, successfully removed $\mathrm{Mn}$ from aqueous solution. The removal efficiency could reach above $99 \%$ at a low initial metal ion concentration $(600 \mathrm{mg} / \mathrm{L})$.

Mechanisms of Mn bioremediation by microbes have been reviewed [51]. Biosorption and biomineralization are the main two methods in the context of metal removal by microorganisms. Metals are uptaken by microbial cells through either the formation of complexes with microbial cell wall constituents or extracellular polymers synthesized and secreted by the microorganisms during the biosorption process, while biomineralization is the organic precipitation of metallic compounds such as oxalates, carbonates, sulfides, hydroxides, and oxides. Environmental characteristics such as extreme conditions (e.g., pH, metal concentration, etc.) influence bioremediation. Linking with different mechanisms, several factors, such as initial metal concentration, $\mathrm{pH}$, contact time, temperature, and inoculation have a profound effect on Mn removal efficiency. The almost linear relationship between biomass and removal efficiency imply that biosorption may play an important role for Mn removal. The functional groups identified on the bacterial surface by FTIR technique include hydroxyl, alkyl, amide, phosphoryl, and phosphoric acid groups, which could possibly be involved in the biosorption of $\mathrm{Mn}$, in accordance with other Bacillus sp [53]. The dependence of the biosorption capacity on $\mathrm{pH}$ is also demonstrated in this study. Experiments show that $\mathrm{pH}$ has a significant effect on the growth of the bacteria $[37$, 54-55], and the B. cereus strain HM-5 grows normally in the weak acid environment $(\mathrm{pH}=5 \sim 6)$. In the course of the experiment, the strain produced precipitation as the $\mathrm{Mn}$ is removed, and the $\mathrm{pH}$ of the solution gradually increased with the growth of the strain, which can be inferred by the mechanism of the removal of manganese from the strain, should it be combined with microbial adsorption and oxidation $\mathrm{Mn}$ [56]. The confirmation of the specific mechanisms also requires analysis of precipitation products, as well as the monitoring of the reaction intermediates. Besides the above process, through SEM micrographs we can know that HM-5 cells were irregular and cracked with the appearance of wrinkles on the surface after absorbing Mn. 
$\mathrm{Mn}$ is a micronutrient required for the growth and survival of bacteria. With the appropriate low concentration (100-800 mg/L) of $\mathrm{Mn}$, it could play a certain role in promoting the growth of the strain. Mn(II) at high concentrations is toxic and it is necessary to remove $\mathrm{Mn}$ (II) from wastewater before returning it to the environment. With the advantages of high metal uptake capacity, satisfactory recovery efficiency, and high metal tolerance, the $B$. cereus HM-5 shows promising results that it could be used as an economical, effective, and green adsorbent for the removal and recovery of heavy metal from a polluted environment.

\section{Acknowledgements}

This work was supported by Major Science and Technology Program of Hunan Province (2017NK1014), the Key Technology R\&D Program of Hunan Province (2016TP2007, 2016TP1014, 2016TP1022), and the Forestry Science and Technology Project of Hunan Province (XKL201731, XLK201825).

\section{Conflict of Interest}

The authors declare no conflict of interest.

\section{References}

1. MARZAN L.W., HOSSAIN M., MINA S.A., AKTER Y., CHOWDHURY A.M.M.A. Isolation and biochemical characterization of heavy-metal resistant bacteria from tannery effluent in Chittagong city, Bangladesh: Bioremediation viewpoint. Egyptian Journal of Aquatic Research. 43 (1), 65, 2017.

2. SOWMYA M., REJULA M.P., REJITH P.G., MOHAN M., KARUPPIAH M., HATHA A.A. Heavy metal tolerant halophilic bacteria from Vembanad Lake as possible source for bioremediation of lead and cadmium. Journal of Environmental Biology. 35 (4), 655, 2014.

3. KHAN M.S., ZAIDI A., WANI P.A., OVES M. Role of plant growth promoting rhizobacteria in the remediation of metal contaminated soils. Environmental Chemistry Letters. 10 (1), 105, 2012.

4. OLIVEIRA, DEPESSENDA S.M.B., GOUVEIA L.C.R., FAVARO S.E.M., DEBORAH I.T. Heavy metal concentrations in soils from a remote oceanic island, Fernando de Noronha, Brazil. Anais Da Academia Brasileira De Ciencias. 83 (4), 1193, 2011.

5. TIAN H.Z., LU L., CHENG K., HAO J.M., ZHAO D., WANG Y., JIA W.X., QIU P.P. Anthropogenic atmospheric nickel emissions and its distribution characteristics in China. Science of the Total Environment. 417-418 (.), 148157, 2012.

6. DUTTON J., FISHER N.S. Bioaccumulation of As, Cd, $\mathrm{Cr}, \mathrm{Hg}(\mathrm{II})$, and $\mathrm{MeHg}$ in killifish (Fundulus heteroclitus) from amphipod and worm prey. Science of the Total Environment. 409 (18), 3438, 2011.

7. TAKAHASHI C.K., TURNER A., MILLWARD G.E., GLEGG G.A. Persistence and metallic composition of paint particles in sediments from a tidal inlet. Marine
Pollution Bulletin. 64 (1), 133, 2012.

8. FADEL M., HASSANEIN N.M., ELSHAFEI M.M., MOSTAFA A.H., AHMED M.A., KHATER H.M. Biosorption of manganese from groundwater by biomass of Saccharomyces cerevisiae. Hbrc Journal. 13 (1), 106, 2017.

9. JARPA M., ROZAS O., SALAZAR C., BAEZA C., CAMPOS J.L., MANSILLA H.D., VIDAL G. Comparison of the chemical precipitation, UV/HOand Fenton processes to optimize removal of chronic toxicity from kraft mill effluents. Desalination \& Water Treatment. 57 (30), 13887, 2016.

10. HAMMUD H.H., ELSHAAR A., KHAMIS E., MANSOUR E.S. Adsorption Studies of Lead by Enteromorpha Algae and Its Silicates Bonded Material. Advances in Chemistry, (2014-11-4). 2014, 2014.

11. FARHAN S.N., KHADOM A.A. Biosorption of heavy metals from aqueous solutions by Saccharomyces Cerevisiae. International Journal of Industrial Chemistry. 6 (2), 119, 2015.

12. MAHMOUD M.E. Water treatment of hexavalent chromium by gelatin-impregnated-yeast (Gel - Yst) biosorbent. Journal of Environmental Management. 147, 264, 2015.

13. FARBO M.G., URGEGHE P.P., FIORI S., MARCEDDU S., JAOUA S., MIGHELI Q. Adsorption of ochratoxin A from grape juice by yeast cells immobilised in calcium alginate beads. International Journal of Food Microbiology. 217, 29, 2016.

14. CHANMUGATHAS P., BOLLAG J.M. Microbial Role in Immobilization and Subsequent Mobilization of Cadmium in Soil Suspensions. Soil Science Society of America Journal. 51 (5), 1184, 1987.

15. YUNSHI L.I., FENG C., XIAOFU W.U., SHI R. A review on the functions of microorganisms in the phytoremediation of heavy metal-contaminated soils. Acta Ecologica Sinica. 6881, 2015.

16. LIAO J., FENG C.L., KE-LIN L.I., XIANG J., JIN L.I. Influence factors and absorption mechanism of $\mathrm{Pb}(\mathrm{II})$ and $\mathrm{Zn}(\mathrm{II})$ by resistant fungus HA. Microbiology China. 254, 2015.

17. XIONG F., HU Y., YIN Y. Biosorption of $\mathrm{Pb}^{2+}$ by extracellular polymeric substances produced by Aspergillus fu-migatus. Acta Scientiae Circumstantiae. 29 (11), 2289, 2009.

18. ZHU M., WEI-HUAN L.I., CHENG X.H., ZUO Y.M. Research progress on biosorption mechanisms of heavy metals by fungus. Industrial Water \& Wastewater. 7, 2012.

19. EMSLEY J. Book Review: Nature's building blocks: an A-Z guide to the elements / Oxford University Press, New York, 538 pp., 2002, ISBN 0-198-50341-5. Astronomy. 87, 2011.

20. ZHONGXING S., GUIMIN W., YONGGEN J. Relationship between Environmental Manganese Exposure and Children 's Neurological Behavior. Shanghai Journal of Preventive Medicine. 29 (4), 288, 2017.

21. JIANG X.Z.S.C.M.Z.X.F.Y. The contents of five trace elements in Panaxnotoginseng and the associated health risk. China Environmental Science. 36 (1), 293, 2016.

22. SUN Z.X., JIANG Y.G., WANG H.Y. Exposure Levels to Manganese in Human Being and Related Control Strategy. Journal of Environmental \& Occupational Medicine. 379, 2011.

23. SHENCUI Z. The Strengthen Effect of Rhizosphere Fungi on Phytoextraction of Soils Contaminated with Cadmium [M]. Hunan Industrial University 2014.

24. DONGXIA D. Research Progress of Soil Heavy Metal 
Pollution Remediation Technology. Biology Teaching. 37 (11), 15, 2012.

25. ZHAO-HAN X.W-J, YING H. Screening, identification and removal efficiency of three manganese resistant strains. Environment and Health. 303, 2016.

26. ZHANG P., DONG W.H., ZHANG Y.L., YANG Z.Y. Research on Isolation and Removal Conditions of a Manganese-resistant Strain. China Rural Water \& Hydropower. 35, 2014.

27. YAPING Y. Research on Manganese removal Mechanism of Pseudomonas sp. 4-05 and the Preparation of Compound Micro-organic Materials [M]. Fujian Normal University, 2012.

28. XUE S., LEI J., ZHOU X., MA Y., ZHOU X., HE Z. Biological characteristics of a manganese resistant microorgnism [M]. 3013, 2011.

29. OUYANG L.N., XIAO-FU W.U., YUN L.I, FENG C.L., CHEN Y.H. Growth and heavy metal accumulation of Paulownia fortunei and Koelreuteria bipinnata in an ecological restoration site of the manganese-ore tailing. China Environmental Science. 908, 2016.

30. KUMAR S., STECHER G., TAMURA K. MEGA7: Molecular Evolutionary Genetics Analysis Version 7.0 for Bigger Datasets. Molecular Biology \& Evolution. 33 (7), 1870, 2016

31. YIQIANYUN A.O., SHEN G.M., WANG M.Y., LIU J.L., PAN Y., LIN H.E. Identification of $\beta$-COP and Sro of Tetranychus cinnabarinus and Their Lethal Effects After Silencing. Scientia Agricultura Sinica. 3529, 2017.

32. LIAO J. Screening of $\mathrm{Pb}, \mathrm{Zn}$ Resistance Microorganism from Pioneer Plant Rhizosphere Soil Microorganism of Lead-zinc Tailings Areas and Studing the Mechanism of Absorption [M]. Central South University of Forestry and Technology, 2015.

33. OVES M., KHAN M.S., ZAIDI A. Biosorption of heavy metals by Bacillus thuringiensis strain OSM29 originating from industrial effluent contaminated north Indian soil. Saudi Journal of Biological Sciences. 20 (2), 121, 2013.

34. YU J., JUANJUAN Q., YING L., HAIDONG G., LILONG Y. Isolation,identification and $\mathrm{Pb}(\mathrm{II})$ biosorption characterization of a lead-resistant strain. Acta Scientiae Circumstantiae. 33 (8), 2248, 2013.

35. ZHANG MEIHUA S.L., ZHU TONG, WANG XINHONG, JIANG JIHONG, ZHAO SHENGKAI Isolation of a Mercury-resistant Fungal Strain and Its Aquatic Biosorption Behavior of $\mathrm{Hg}(\mathrm{II})$. Environmental Science \& Technology. (s2): 1-6, 2015.

36. YAN B., ZHOU J., YUANGAO L.I., QIAN S., HAIYAN F.U., TIAN C., LIU J. Optimization and characteristics of Ni (II) biosorption by the bacterial strain Dyella ginsengisoli LA-4. Acta Scientiae Circumstantiae. 30 (9), 1798, 2010

37. HU Y., LI X., WANG H., SHAO Y., ZHANG J., HAN Z., MA S. Screening of chromium resistance strains and their biological and absorption characteristics. Chinese Journal of Environmental Engineering. 8 (6), 2585, 2014.

38. HONGHUI M.L.L.M.F.G.Z. Cadmium Adsorption Characterization of Cadmium-resistant Fungal Strain Paecilomyces lilacinus 6-20p., 7 (3), 241, 2017.

39. JIA C., ZHANG Y., ZHU Y., WANG H., WANG J. Isolation,Identification and Adsorption Characteristics of an Highly Nickel-resistant Stenotrophomonas sp. Strain. Environmental Science \& Technology. 55, 2014.

40. GONTE R., BALASUBRAMANIAN K. Heavy and toxic metal uptake by mesoporous hypercrosslinked SMA beads: Isotherms and kinetics. Journal of Saudi Chemical Society.
20 (S1), S579, 2016.

41. WANG Y., FENG H.E., YOU J., CHEN K., BINGQIN X.U., LIN Y. Screening and Identification of a Manganeseresistant Strain and Its Manganese Biosorption Conditions. Acta Agriculturae Boreali-Occidentalis Sinica. 22 (7), 193, 2013.

42. SHAOWEN L. Screening and identification of mercury resistant Fungi and study of its application potential. [M]. Chinese Academy of Forestry, 2016.

43. LUJI Y. Screening and Growth Characteristics of a Heterotrophic Nitrification Bacterium. Biotechnology Bulletin. 32 (4), 168, 2016.

44. TINGTING W. Microbial adsorption of heavy metals and its influencing factors. Biology Teaching. 9, 2012

45. CHEN Y.H., XIANG J., WU X.F., FENG C.L., YUAN S.W. Isolation, identification and biosorption ability of three $\mathrm{Pb}^{2+}$ and $\mathrm{Zn}^{2+}$ tolerant bacterial strains. Chinese Journal of Ecology. 34 (9), 2665, 2015.

46. QIUYUE S., ZHIQIANG Z., YUEFANG Z., WEILIN S. Isolation and Identification of a Cadmium - tolerant Bacterium and Optimization of Its Adsorption Conditions. Soils. (3), 615, 2016.

47. HUIFEN L.I., LIN Y., WANG N., GUO J. Screening and identification of a heavy metal-resistant strain and optimization of its zinc biosorption conditions. Huanjing Kexue Xuebao. 30 (11), 2189, 2010.

48. SI WANGTONG L.L., LIU JUMEI, LI XIAOLONG, WANG ZHIYONG, SHI CHUNFANG, CAI LU, JIANG HAIMING Selection of Denitrifying PhosphorusRemoving Bacteria and Its Characteristics. Xinyang Normal University. 210, 2017.

49. HOU Y., CHENG K., LI Z., MA X., WEI Y., ZHANG L., WANG Y. Biosorption of Cadmium and Manganese Using Free Cells of Klebsiella sp. Isolated from Waste Water. Plos One. 10 (10), e0140962, 2015.

50. BARBOZA N.R., MORAIS M.M.C.A., QUEIROZ P.S., AMORIM S.S., GUERRASÁ R., LEÃO V.A. High Manganese Tolerance and Biooxidation Ability of Serratia marcescensIsolated from Manganese Mine Water in Minas Gerais, Brazil. Frontiers in Microbiology. 8, 1946, 2017.

51. BARBOZA N.R., GUERRA-SÁ R., LEÃO V.A. Mechanisms of manganese bioremediation by microbes: an overview. Journal of Chemical Technology \& Biotechnology. 91 (11), 2733, 2016.

52. CERRATO J.M., FALKINHAM J.O., DIETRICH A.M., KNOCKE W.R., MCKINNEY C.W., PRUDEN A. Manganese-oxidizing and -reducing microorganisms isolated from biofilms in chlorinated drinking water systems. Water Research. 44 (13), 3935, 2010.

53. HASAN H.A., ABDULLAH S.R.S., KOFLI N.T., KAMARUDIN S.K. Isotherm equilibria of $\mathrm{Mn}^{2+}$ biosorption in drinking water treatment by locally isolated Bacillus species and sewage activated sludge. Journal of Environmental Management. 111 (6), 34, 2012.

54. DENG X., WANG P. Isolation of marine bacteria highly resistant to mercury and their bioaccumulation process. Bioresource Technology. 121 (7), 342, 2012.

55. MA YONG-SONG L.X., LI ZHEN-ZHEN, WANG PEI-JIE Isolation and Identification of a Nickel-resistant and Petroleum Hydrocarbon Degrading Strain and Its Biological Characteristics. Biotechnology Bulletin. 33 (10), 169,2017

56. ZHANG P., DONG W.H., ZHANG Y.L., YANG Z.Y. Research on Isolation and Removal Conditions of a Manganese-resistant Strain. China Rural Water \& Hydropower. 35, 2014. 